\title{
The upsurge of interest in Indigenous health in the 1950s and 1960s
}

\section{Barry Christophers' letters to the MJA editor about Indigenous health}

David P Thomas

\begin{abstract}
During the 1950s and 1960s, there was a dramatic explosion in the number of letters to the editor about Indigenous health published in the MJA, reflecting increased reader interest. The letters from Barry Christophers were part of the Federal Council for Aboriginal Advancement's largely successful campaign for equal civil rights for Aboriginal and Torres Strait Islander people. His letters not only drew attention to discriminatory legislation and policies, but also emphasised the structural (especially economic) determinants of Indigenous ill-health, and the negative impact on Indigenous people of racist medical representations. (MJA 2004; 180: 521-523)
\end{abstract}

THERE WAS LITTLE INTEREST in the health of Aboriginal and Torres Strait Islander peoples in the $M \mathcal{F} A$ before 1950 . Early research portrayed Aboriginal people as being from an inferior and primitive race, the demise of which was thought to be inevitable. For example, in 1924, a case series of Aboriginal psychiatric patients was introduced by stating that:

Contact with civilization, phthisis and other diseases, mixed breeding and general racial decay are the order of the day. In a few years this line of research will be closed for ever. Whatever may be one's sentimental views on the passing of the primitive peoples, from the scientific or even the utilitarian aspect it will be more than unfortunate if our records are not completed before they vanish. ${ }^{1}$

Any research on Aboriginal and Torres Strait Islander peoples before the 1960 s was not primarily about improving their health. It was about using Indigenous health research to improve understanding of the health problems of white Australians, and about collecting information about Aboriginal people for science before the race became extinct. ${ }^{2}$

Letters to the editor are the voice of the readers of the $M \mathcal{F} A$. Letters do not have the same academic status as journal articles, but three readership surveys in the 1950s and 1960s showed that the letters pages were the most read section of the $M \mathcal{F} A .^{3-5}$ An editorial marking the 50th anniversary of the $M \mathcal{H} A$ in 1964 described the number of letters to the editor as a barometer of the interest of readers in a journal. ${ }^{6}$ Most letters received by the $M \mathcal{F} A$ were published. $^{7}$

Before 1950, there were only 13 letters about Indigenous Australians published in the $M \mathcal{F} A$. Readers did not write more than a single letter to the editor in response to any $M \mathcal{F} A$ publication about Indigenous people until 1952, when an editorial announced that a new university scholarship for an Aboriginal student marked a change from the brutal past of the colonial encounter, and decried the obstacles caused by "the monstrous fiction of racial superiority and inferior-

Cooperative Research Centre for Aboriginal Health, Darwin, NT. David P Thomas, PhD, FAFPHM, Senior Research Fellow. Reprints will not be available from the author. Correspondence: Dr David P Thomas, Menzies School of Health Research, PO Box 41096, Casuarina, NT 0811. davidt@menzies.edu.au

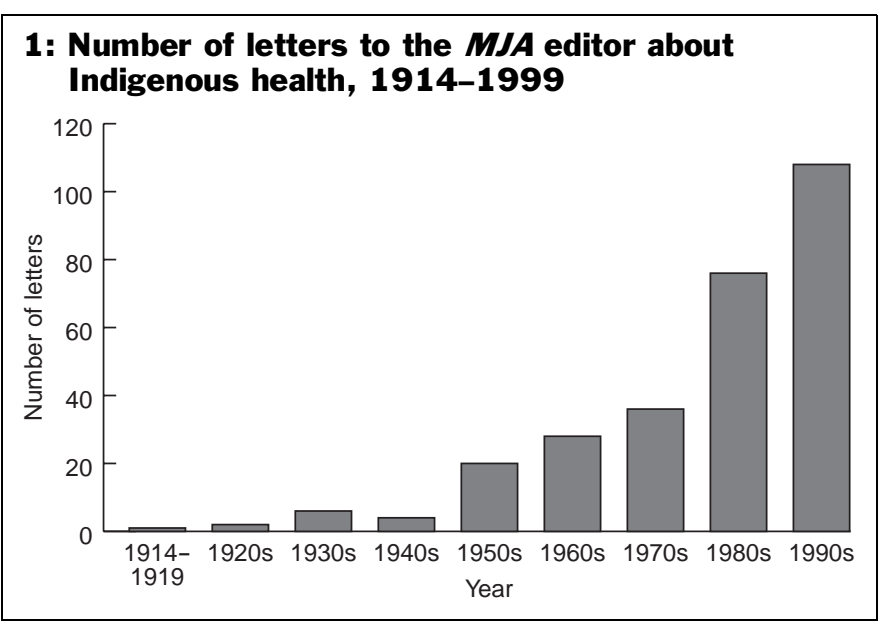

ity". Writers of editorials had much greater freedom of language and freedom to express opinions than writers of scientific articles. Letter writers had even more freedom, and were often those with the strongest opinions.

Four letters were published in response to the editorial: one claimed that it was possible to discuss Aboriginal people's inferiority (but did not assert a biological basis for this inferiority); the others replied that doctors should treat "aborigines as our equals" and that their problems were due to racism. ${ }^{9-12}$

A dramatic increase in letters to the editor about Indigenous health began in the 1950s (Box 1). This increase occurred before a large increase in the number of all letters later in the decade. Letters to the editor accounted for a quarter (48/200) of the publications on Indigenous health in the $M \mathcal{F} A$ in the 1950 s and 1960 s, increasing to more than a third in the 1980 s and 1990 s $\left(76 / 204\right.$ and 108/203). ${ }^{2}$

\section{Barry Christophers' letters to the MJA editor}

Barry Christophers (Box 2) wrote 25 letters to the $M \mathcal{F A}$ about Indigenous health between 1956 and 1969. He wrote half the letters to the editor about Indigenous health in this period (and a similar number of letters not about Indigenous health), but he did not write any longer articles about Indigenous health. At the time, Christophers was a general 
practitioner in the inner-city Melbourne suburb of Richmond, and an activist in the Federal Council for Aboriginal Advancement (FCAA) (in 1964 the name was changed to the Federal Council for the Advancement of Aborigines and Torres Strait Islanders [or FCAATSI]) (Box 3). His letters may not have reflected the views of the majority of $M \mathcal{F} A$ readers, but they draw attention to one doctor's role in events that led to great changes in the relationship between Indigenous and non-Indigenous Australians.

In 1957, Christophers drew $M \mathcal{F} A$ readers' attention to claims of starvation in the Warburton Ranges made by Pastor (later Sir) Doug Nicholls and Western Australian members of parliament William Grayden and Stan Lapham. ${ }^{16,17}$ He often sent similar versions of his $M \mathcal{F} A$ letters to various newspapers, but he saw a special role for doctors. He explained to me that he wrote to the $M \mathcal{F} A$ because doctors were "important folk in the community" who influenced people's views and attitudes (Dr Barry Christophers, personal communication). Christophers was always careful to not criticise the work of individual doctors; his targets were governments and bureaucrats, and their discriminatory policies and legislation. He did not choose to either alienate his audience or undermine the authority of the medical voice, which could continue to be used for other activities. In contrast, other writers in the $M \mathcal{F} A$ questioned the capacity of non-medically trained activists like Nicholls to speak authoritatively on Indigenous health matters. ${ }^{18}$

Christophers wrote many letters to the $M \mathcal{F A}$ about FCAA and FCAATSI campaigns to highlight and then remove discriminatory legislation and policies affecting Indigenous people. He wrote about the restriction of the movement of Aboriginal people in Western Australia by the "leper line". ${ }^{19,20} \mathrm{He}$ wrote four letters to the $M \mathcal{F} A$, and many more to newspapers, supporters, bureaucrats and politicians, about the exclusion of Queensland Aboriginal patients with tuberculosis from the generous allowance paid to other TB patients to encourage convalescence and treatment. ${ }^{21} \mathrm{He}$ explained that the exclusion was "understandable", even if abhorrent, only because it was much higher than the very low wages then being paid to Aboriginal people in northern Australia. ${ }^{22}$

Christophers was secretary of FCAA's Equal Wages Committee and, in the $M \mathcal{F} A$ and elsewhere, he repeatedly emphasised economic causes (and solutions) for Indigenous people's suffering and ill-health. While many of his contemporaries blamed Aboriginal behaviour, just as their predecessors had blamed Aboriginal people's inferior racial characteristics, Christophers focused on deeper structural causes of ill-health. In response to a claim that alcohol restriction needed to continue and citizenship to be opposed, he argued that Aboriginal alcohol abuse was merely a "symptom" of the "disease" of "lack of citizenship, low wages and colour prejudice". ${ }^{23}$ In spite of his attention to structural determinants of health, he did not portray Indigenous people as passive victims; their actions were constrained, but not entirely determined, by racist, white institutions; nor did they just drift or follow biological urges, as others had claimed. His concern with the WA "leper line" was due to its interference with the attempts by Aboriginal "liberators" to "assist some of their not so fortunate friends". ${ }^{20}$ Aboriginal people could be their own liberators and the liberators of other Aboriginal people, not just a problem to be solved by others.

In the Northern Territory, he complained about withholding of blood transfusions from Aboriginal patients, inferior medicine chests required to be kept by employers of Aboriginal labour (compared with those at Royal Flying Doctor Service outposts), and legislation about Aboriginal people dying intestate. ${ }^{24-28} \mathrm{He}$ was concerned that this legislation about the estates of Aboriginal people had been taken directly from the Mental Defectives Act: "The psychological trauma inflicted upon aborigines by regarding them and treating them as mental defectives and bankrupts must be immeasurable". ${ }^{27}$ He similarly suggested that writers should avoid certain words, used by earlier conventions to describe Aboriginal people, that might inadvertently cause similar "psychological trauma" because of their negative metaphorical associations, or because he thought they were inaccurate or no longer acceptable. ${ }^{29}$

Christophers did not just promote positive over negative words and representations of Indigenous people, he investigated the portrayal of power in these representations and their colonial context. But no one questioned the fact that these representations of Indigenous people were created in their absence by non-Indigenous doctors. Enormous social changes since the 1950s in Australia make this omission seem obvious today. No longer can doctors expect to be unchallenged as the only authoritative voice on health matters. No longer can non-Indigenous people remain untroubled about the colonial context of their position when they speak about Indigenous people's lives — or if they try to speak for Indigenous people.

\section{After the 1967 referendum}

FCAATSI's 10-year campaign successfully led to $90.77 \%$ of voters in the 1967 referendum approving the deletion of the two discriminatory references to Indigenous people in the 


\section{3: The Federal Council for Aboriginal Advancement (FCAA) and the 1967 referendum}

The first meeting of the FCAA declared its goal as equal civil rights for Aboriginal people (equal living conditions and pay and the removal of discriminatory legislation). In the 1960s, FCAA began to assert the need for different Indigenous rights (like land rights), not just equal civil rights. ${ }^{13,14}$ Torres Strait Islanders were acknowledged when the organisation changed its name to the Federal Council for the Advancement of Aborigines and Torres Strait Islanders (or FCAATSI) in 1964.

Historian Peter Read has asserted that there were two dominant groups in the FCAA in its early years: the unions (and associated leftists, such as Christophers) and the churches. These groups included Aboriginal pastors like Doug Nicholls and Aboriginal unionists like Bert Groves and Joe McGinness, but these men had no special status as Indigenous people. FCAA and FCAATSI were "multi-racial" (or anti-racial) organisations, not Indigenous organisations - all people involved were treated "equally" although, in practice, they were largely run by non-Indigenous people. ${ }^{13}$ The emphasis on the equality of Indigenous and nonIndigenous members reflected the organisations' campaign goals for equal rights for Indigenous Australians.

FCAATSI's greatest public acclaim came with the success of its campaign for the 1967 referendum. The Australian Constitution had stated in Section 51 that the Commonwealth Parliament had the power to make "special laws" for the "people of any race, other than the aboriginal race in any State". Section 127 stated that "aboriginal natives shall not be counted" in the populations of the states. While the referendum merely removed these two discriminatory references to Aboriginal people in the Constitution, FCAATSI's campaign for the referendum was part of the larger social movement towards other, more significant equal rights. The referendum is now publicly and fondly (even though legalistically incorrectly) remembered for finally granting equal rights to Aborigines, including "citizenship" and the right to vote, as well as being associated with equal rights to drink alcohol. ${ }^{15}$

Constitution (Box 3). FCAATSI folded 10 years later after a decade of internal divisions concentrated on concerns about non-Indigenous control of the organisation. ${ }^{13}$ In part due to FCAATSI's successes, attention had turned from equality to special Indigenous rights, like land rights, and Indigenous control of Indigenous lives. In the decades since the referendum, hundreds of Indigenous-controlled organisations, including health services, have been established and become successful. In more recent times, however, a new official and grass-roots coalition promoting "reconciliation" between Indigenous and non-Indigenous Australians has emerged with prominent Indigenous and non-Indigenous leaders and members. While clearly lobbying in a different time and for different causes, this present-day coalition or social movement evokes memories of FCAATSI. This reconciliation movement has proved to be extraordinarily popular among both non-Indigenous and Indigenous Australians and very effective in spite of the considerable early and continued scepticism of many Indigenous people. ${ }^{30}$

With time, many people have forgotten or not heard of the activism and achievements of FCAATSI and its members like Barry Christophers. The dramatic changes in Indigenous lives and health that began in the 1950 s and $1960 \mathrm{~s}$ facilitated greater changes in the following decades. Joe McGinness, a Kungarakan man who lived in Cairns, was the
President of FCAA (and FCAATSI) for most of its 20-year history. Christophers nominated him for the position in 1961 when he was first elected, and worked closely with him on many campaigns; they remained friends many years later. Sadly, Joe McGinness died in July last year.

\section{Acknowledgements}

Most of the research for this article was for a PhD supported by the National Health and Medical Research Council Aboriginal Health Postgraduate Research Scholarship 978508. I thank my PhD supervisors Komla Tsey and Peter d'Abbs. I am grateful to Barry Christophers for generously sharing his memories about the 1950s and 1960s.

\section{Competing interests}

None identified.

\section{References}

1. Bostock J. Insanity in the Australian Aboriginal and its bearing on the evolution of mental disease. Med J Aust 1924; 2 (Suppl): 459-464.

2. Thomas DP. Reading doctors' writing: race, politics and power in Indigenous health research, 1870-1969. Canberra: Aboriginal Studies Press; 2003

3. Anderson D. The post-graduate education of the practising doctor. Med J Aust 1955; 2: 1039-1041

4. Anderson DJ. How the doctor looks at his journals. Med J Aust 1961; 1: 727-729

5. King K. The position of leading articles [letter]. Med J Aust 1989; 150: 108.

6. Our first fifty years [editorial]. Med J Aust 1964; 2: 27-31

7. Sixty years old [editorial]. Med J Aust 1974; 2 : 1-2

8. The Australian Aboriginal and ourselves [editorial]. Med J Aust 1952; 2: 633-634

9. Hogg JB. The Australian Aboriginal and ourselves [letter]. Med J Aust 1952; 2: 793-794.

10. Lahz JRS. The Australian Aboriginal and ourselves [letter]. Med J Aust 1952; 2: 868.

11. Dark EP. The Australian Aboriginal and ourselves [letter]. Med J Aust 1952; 2 : 895-896.

12. Duguid C. The Australian Aborigines and ourselves [letter]. Med J Aust 1953; 1: 80 .

13. Read P. Cheeky, insolent and anti-White: the split in the Federal Council for the Advancement of Aboriginal and Torres Strait Islanders - Easter 1970. Aust $J$ Politics History 1990; 36: 73-83.

14. Bandler F. Turning the tide: a personal history of the Federal Council for the Advancement of Aborigines and Torres Strait Islanders. Canberra: Aboriginal Studies Press; 1989.

15. Attwood B, Markus A (in collaboration with Edwards D and Schilling K). The 1967 Referendum, or when Aborigines didn't get the vote. Canberra: Aboriginal Studies Press, 1997.

16. Christophers BE. The medical profession and the plight of the Aborigines [letter] Med J Aust 1957; 1: 659-660.

17. Christophers BE. The Aborigines of the Warburton range area [letter]. Med J Aust 1957; 2: 842 .

18. The welfare of Aborigines in Western Australia [editorial]. Med J Aust 1957; 1: 837-838.

19. Christophers BE. Aborigines and leprosy in Western Australia [letter]. Med J Aust 1961; 1: 147

20. Christophers B. Aborigines and leprosy in Western Australia [letter]. Med J Aust 1961; 1 : 345.

21. Taffe $\mathrm{S}$. Health, the law and racism: the campaign to amend the discriminatory clauses in the Tuberculosis Act. Labour History 1999; 76: 41-58.

22. Christophers B. Tuberculosis allowances [letter]. Med J Aust 1963; 2: 296.

23. Christophers B. The future of the Australian Aboriginal [letter]. Med J Aust 1959; 1: 29-30.

24. Christophers BE. Blood transfusions for Aborigines in the Northern Territory [letter]. Med J Aust 1962; 1: 25

25. Christophers BE. Blood transfusions for Aborigines in the Northern Territory [letter]. Med J Aust 1962; 1: 143.

26. Christophers BE. Medicine chests for Aboriginal labourers in the Northern Territory [letter]. Med J Aust 1964; 1: 420.

27. Christophers B. The property of Aborigines [letter]. Med J Aust 1962; 1: 537.

28. Christophers BE. The estates of Aborigines [letter]. Med J Aust 1963; 2: 119.

29. Christophers BE. Surgery in ulcerative colitis [letter]. Med J Aust 1964; 2: 609-610.

30. Anderson I. Reconciliation and policy reform: is there a link? Aust N Z J Public Health 1999; 23: 231-232

(Received 17 Sep 2003, accepted 7 Jan 2004) 